\title{
PENGENALAN DAN PENANAMAN TANAMAN SAYUR-SAYURAN PADA TK PERTIWI XI KECAMATAN PELAYANAGAN KOTA JAMBI
}

\author{
Anis Tatik Maryani ${ }^{1}$, Nyimas Myrna Elsa Fathia ${ }^{1}$ \\ ${ }^{1)}$ Pertanian, Universitas Jambi \\ Email: atatikmaryani25@gmail.com
}

\begin{abstract}
Abstrak
Pendidikan pertanian pada usia dini sangat penting karena melihat anak zaman sekarang yang cenderung minim, maka dari itu pembelejaran tentang pertanian dimulai dari sejak duni agar dapat menghasilkan petani yang cakap dan tercetak pakar-pakar yang profesioanl di bidang pertanian. Pengenalan edukasi pertanian memang harus diterapkan sejak dini pada anak-anak, sehingga memunculkan kecintaan terhadap lingkungan sekitar. Salah satunya memanfaatkan halaman sekolah agar selalu terlihat asri, indah dan menarik melalui budidaya berbagai macam komoditas hortikultura maupun komoditas lainnya. Salah satunya adalah pengenalan tanaman sayur-sayuran, yang bertujuan meningkatkan kepedulian murid pada lingkungan adalah memberikan ilustrasi dampak penanaman terhadap lingkungan.

Hasil post test menunjukkan 90\% murid TK Pertiwi XI Telah mengetahui cara bercocok tanam dan dapat merawat tanaman dengan baik. Selain itu, seluruh guru, orang tua dan murid juga senang dengan kegiatan ini, sebelumnya hasil wawancara dan pre test menunjukkan $81 \%$ murid TK Pertiwi XI belum pernah merawat tanaman, yang menjadi penyebab dari kurangnya kecintaan mereka pada tanaman adalag 69\% diantaranya belum mengtahui cara merawat tanaman $12 \%$ tidak memiliki tanaman.
\end{abstract}

Kata kunci: Literasi Lingkungan, Hortikultura, Usia Dini

\section{PENDAHULUAN}

Pendidikan anak usia dini yang secara umum belum banyak mengontekstualisasikan kurikulum tentang bidang pertanian ke dalam keseharian pembelajarannya. Pendidikan pertanian pada usia dini sangat penting karena melihat pendidikan pertanian pada usia dini sangat penting karena melihat minat anak zaman sekarang yang cenderung minim padahal sektor pertanian beberapa tahun kedepan sangat membutuhkan generasi muda yang akan membangun pertanian Indonesia. Kurikulum pendidikan yang menjadi pedoman pengajaran pada anak kurang menekankan pengenalan dunia pertanian dan lingkungan. Sehingga, anak-anak Indonesia kurang memiliki minat untuk mengembangkan pertanian di negaranya. Rumusan Masalah Berdasarkakn latar belakang di atas, maka masalah yang dapat dirumuskan adalah menurunnya minat pertanian pada anak yang tinggal di kawasan perkotaan, karena pertanian masih dianggap kotor dan miskin, maka dari itu tidak ada salahnya jika pembelajaran tentang pertanian dimulai dari sejak dini agar dapat menghasilkan petani yang cakap nantinya dan tercetak pakar-pakar yang profesional di bidang pertanian. Untuk itu perlu adanya pengenalan dunia pertanian yang menyenangkan pada generasi muda khususnya anak usia dini, agar adanya regenerasi di kemudian hari (Yati, 2016).

Pengenalan edukasi pertanian memang harus diterapkan sejak dini pada anak-anak, sehingga memunculkan kecintaan terhadap lingkungan sekitar. Salah satunya memanfaatkan halaman sekolah agar selalu terlihat asri, indah dan menarik melalui budidaya berbagai macam komoditas hortikultura maupun komoditas lainnya. Mengingat anak-anak TK adalah tunas bangsa sebagai penerus pembangunan pertanian, perlu diarahkan pada sebuah mental yang mencintai lingkungannya. Karena itu diperlukan perilaku positif dari bagaimana pola atau cara berfikir mereka sejak usia dini. Bermuara dari itu, perlu diajarkan kepada anak-anak sejak dini mengenal dunia pertanian sebagai bentuk kecintaan terhadap alam dan lingkungan sekitar untuk mencegah kerusakan lingkungan alam di sekitarnya dan pengembangan upaya-upaya untuk memperbaiki kerusakan alam yang sudah terjadi. (Al-Anwari dan Amirul, 2014).

Melalui pengenalan dan penanaman tanaman hortikultura pada anak-anak dikenalkan dengan dunia pertanian. Hortikultura adalah bagian dari pertanian dalam arti sempit dengan fokus pada budidaya tanaman kebun, seperti tanaman sayur, tanaman buah, tanaman hias dan tanaman obat.

\section{METODE (TIMES NEW ROMAN 10 CETAK TEBAL)}

Pelaksanaan kegiatan diawali dengan mengadakan sosialisasi pengenalan dunia pertanian khususnya hortikultura pada murid TK Pertiwi XI, dengan bentuk pemberian pertanyaan tentang pertanian (pre test) dan games mengenai pertanian. Pada pertemuan selanjutnya murid diarahkan untuk lebih peduli terhadap lingkungan sekitar dengan mengadakan bersih-bersih bersama memanfaatkan sampah botol plastic sebagai wadah media tanam yang unik dan kreatif. Setelah wadah media tanam selesai dibuat, dilanjutkan dengan kegiatan budidaya tanaman berupa penanaman tanaman sayur pada vertikultur serta penanaman pada hidrogel. Kegiatan utama dilakukan setiap hari, dimana murid diwajibkan untuk merawat tanamannya agar tetap segar.

Tindak lanjut evaluasi program dilakukan dengan cara memberikan post test pada murid TK Pertiwi XI, staf pengajar dan orang tua murid yang berisikan evaluasi mengenai apa yang telah mereka dapatkan baik dari kemanfaatan 
maupun kesan selama kegiatan berlangsung, dengan harapan kegiatan ini dapat memberikan solusi terhadap permasalahan yang terjadi dan program ini dapat diterapkan di TK atau sekolah lainnya yang memilki permasalahan yang sama.

\section{HASIL DAN PEMBAHASAN}

Program kreativitas maha murid dibidang pengabdian masyarakat yang telah berjalan selama empat bulan dan melalui beberapa tahapan pelaksanaan. Langkah awal yang dilakukan tim adalah survey dan pengumpulan data atau permasalahan yang ada di TK melalui wawancara dengan staf pengajar, kepala sekolah, serta orang tua murid. Selain itu, pemberian pre test pada murid juga dilakukan sebagai sasaran utama program ini.

Berdasarkan hasil wawancara dan pre test menunjukan $81 \%$ murid TK Pertiwi XI belum pernah merawat tanaman yang menjadi penyebab dari kurangnya kecintaan mereka pada tanaman adalah $69 \%$ diantaranya belum mengetahui cara merawat tanaman dan $12 \%$ tidak memiliki tanaman. Hal ini ternyata sangat dipengaruhi oleh lingkungan, dimana $100 \%$ murid TK Pertiwi XI memiliki latar belakang orang perkotaan yang tinggal di seberang Kota Jambi tidak jauh dari TK Pertiwi XI. Masyarakat perkotaan memiliki karakteristik lebih individual, dinamis, heterogen dan bermata pencarian non-agraris (Nilawati et al., 2019). Faktor inilah yang mempengaruhi kurangnya minat murid pada pertanian. Semakin tingginya pembangunan suatu daerah akan mempengaruhi peningkatan kualitas lingkungan hidup dan meningkatnya volume sampah, sehingga perlu adanya sosialisasi mengenai lingkungan hidup dan pemanfaatan lingkungan yang ditanami dengan tanaman sayur-sayuran untuk generasi muda. Berdasarkan hasil wawancara dengna orang tua dan staf pengajar di TK Pertiwi XI, kurangnya kepedulian anak terhadap lingkungan menjadi salah satu permasalahan, sehingga staf pengajar dan orang tua menyarankan untuk membuat kegiatan yang lebih efektif dalam meningkatkan kecintaan pada lingkungan.

Salah satu kegiatan pengenalan tanaman sayur-sayuran yang bertujuan meningkatkan kepedulian murid pada lingkungan adalah dengan memberikan ilustrasi dampak penanaman tanaman terhadap lingkungan. Setelah kegiatan ini dilaksanakan kepedulian murid pada lingkungan meningkat. Meningkatnya kepedulian murid pada lingkungan juga berkorelasi positif dengan penigkatan minat anak terhadap pertanian, karena anak semakin senang untuk menanam pada pot hasil karya mereka. Selain itu, setelah kegiatan menanam murid terbiasa untuk merawat tanaman, karena mereka telah memiliki tanaman asuh.

Pemilihan jenis tanaman, yaitu tanaman pakcoi, kangkung dan selada dapat menghindarkan anak dari rasa bosan, karena tanaman sayur-sayuran cepat tumbuh apabila rutin dirawat. Setelah rangkaian kegiatan penanaman dilaksanakan, staf pengajar, orang tua dan murid diberikan post test yang bertujuan untuk mengetahui perkembangan minat anak terhadap cara bercocok tanam. Hasil post test menunjukan $90 \%$ murid TK Pertiwi XI telah mengetahui cara bercocok tanam dan dapat merawat tanaman dengan baik. Selain itu, seluruh guru, orang tua dan murid juga senang dengan kegiatan ini. Bahkan, setelah berdiskusi dengan staf pengajar, mereka bersedia menjadikan bercocok tanaman sayuran sebagai bagian dari kurikulum di TK.

\section{KESIMPULAN}

1. Pengenalan tanaman sayuran (Horticulture for Kids) merupakan program yang berfokus pada pengenalan pertanian dan peningkatan kepedulian lingkungan pada anak khususnya murid TK Pertiwi XI, Program ini terdiri dari beberapa tahapan, yaitu tahap persiapan, tahap pengenalan pengenalan tanaman sayuran, tahap penanaman, tahap pendampingan, tahap panen, dan tahap tindak lanjut.

2. Berdasarkan hasil pre test dan post test yang telah dilakukan terdapat peningkatan minat murid pada pertanian sebesar $81 \%$ serta peningkatan kepedulian murid pada lingkungan sebesar 35\%. Selain itu, kreativitas mereka semakin terasah dengan kegiatan pemafaatan plastik untuk menjadi pot unik yang akan digunakan sebagai wadah media tanam tanaman hortikultura.

3. Metode pengenalan tanaman sayuran yang didominasi dengan pekerjaan dalam kelompok, membiasakan para murid untuk bekerjasama dalam kelompok, sehingga dapat mengikis sikap individual yang menjadi salah satu karakter masyarakat perkotaan.

\section{DOKUMEN TAMBAHAN}



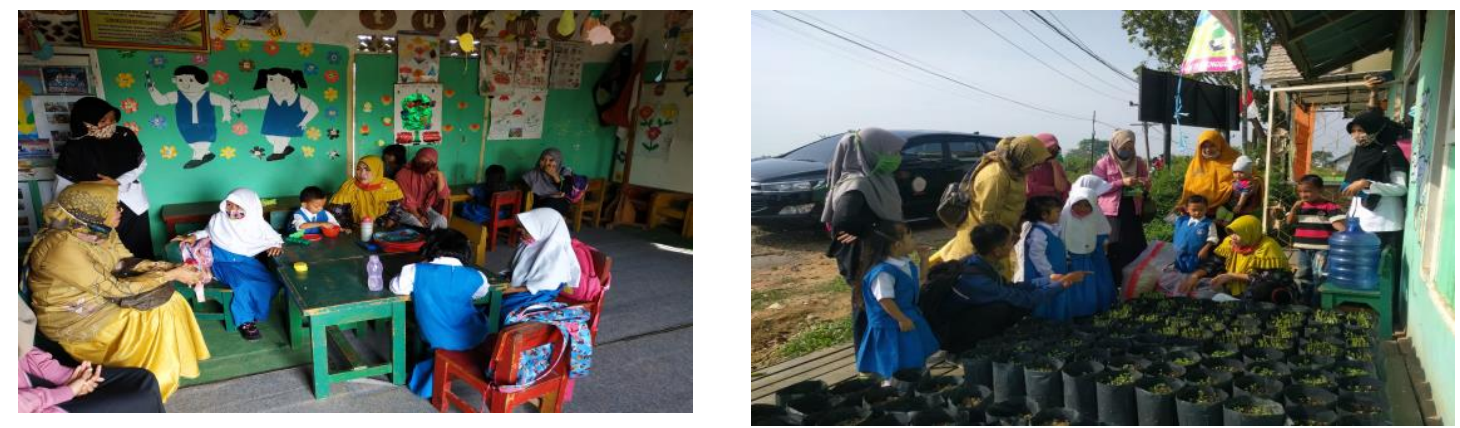

Tim pengabdian menjelaskan kepada murid TK Pertiwi dan orang tua murid tentang awal penanaman tanaman sayur-sayuran dari mulai pembibitan hingga memindahkan bibit ke dalam polybag
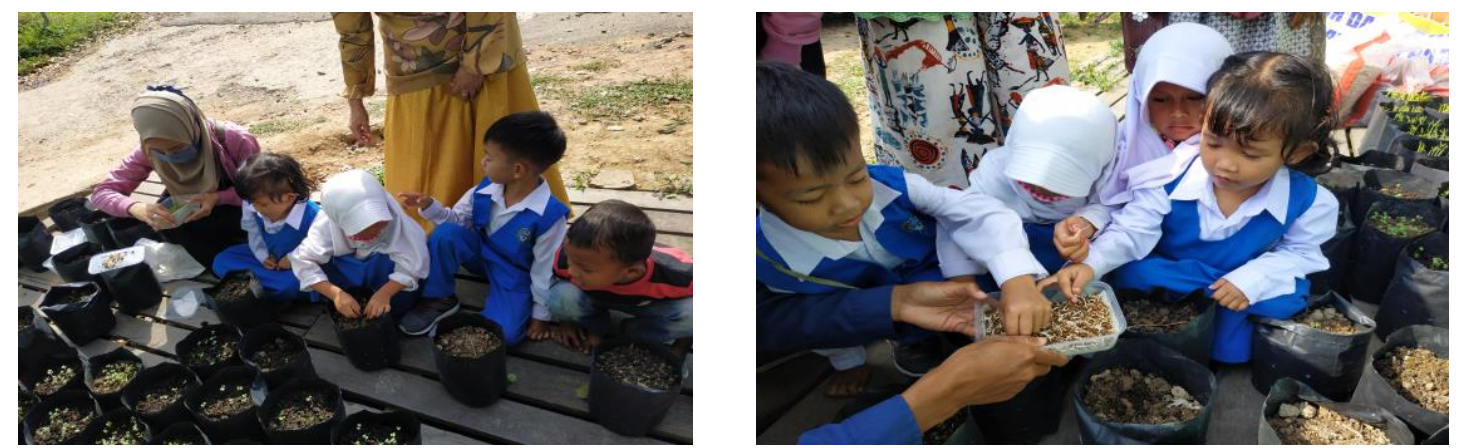

Anak-anak TK Pertiwi langsung tertarik melihat bibit tanaman sayur-sayuran dan langsung antusias untuk mencoba menanam bibit tersebut kedalam polybag yang sudah disiapkan

\section{UCAPAN TERIMA KASIH}

Puji dan syukur kami panjatkan kehadirat Tuhan Yang Maha Esa yang telah memberikan kesehatan dan kesempatan kepada kami selaku Tim Pengabdian Pada Masyarakat untuk dapat menyelesaikan proposal pengabdian dengan judul "Pengenalan dan Penanaman Tanaman Sayur-sayuran Pada TK Pertiwi XI Kecamatan Pelayangan Kota Jambi" dengan baik.

Tim Pengabdian Pada Masyarakat menyadari bahwa dalam menyelesaikan penyusunan laporan ini tidak terlepas dari bantuan dan kesempatan.motivasi. petunjuk dan saran baik secara langsung maupun tidak langsung dari berbagai pihak. Terutama dari Bapak Rektor Universitas Jambi, Direktur Pascasarjana Universitas Jambi, Ketua LPPM UNJA, Reviewer dan lembaga mitra di TK Pertiwi XI Kecamatan Pelayangan Kota Jambi.

\section{REFERENSI}

Yati, Padmi. 2016. Pendidikan Karakter Anak Usia Dini Melalui Metode Pembelajaran Field Trip. Jurnal Lentera I. 28(1);123-139.

Al-Anwari, Amirul Mukmin, 'Strategi Pembentukan Karakter Peduli Lingkungan Di Sekolah Adiwiyata Mandiri', Ta'dib, XIX (2014), 227-52.

Anita Nilawati, Hery Muhammad A dan Rina Herowati. 2019. Pelatihan Mananam dan Merawat Tanaman Obat Keluarga di TK Ra Al Kautsar Surakarta. Jurnal Pengabdian Kepada Masyarakat. Vol. 3 NO. 1.

Fitriatien, S.R., Rachmawati, N.A.J., Rahmah,N., Safitri,D.A., Pahlevi,M.R., Natsir, N.M.W. (2017). Kegiatan PenanamanTanaman ObatKeluarga (TOGA) Sebagai Salah Satu Usaha Pemberdayaan Siswa SDN Dermo Guna Dalam Menumbuhkan Kepedulian Kesehatan Keluarga. Abadimas Adi Buana Vol. 02, Nomor 2. 